\title{
Tarptautinèse operacijose dalyvaujančių karių kultūrinio išprusimo raiška
}

\begin{abstract}
Straipsnyje pateikiamas kultūrinio išprusimo modelis, pritaikytas tarptautinèse operacijose dalyvaujančių karių kultūrinio išprusimo raiškos vertinimui, ir empiriškai įvertinama tarptautinèse operacijose dalyvavusių Lietuvos karių kultūrinio išprusimo raiška. Pirmojoje straipsnio dalyje apibrèžiamos kultūrinị išprusimą sudarančios kompetencijos ir jų igijimo metodai ir, remiantis straipsnyje atskleidžiamais karių kultūrinio išprusimo ypatumais, suformuojamas kultūrinio išprusimo modelis. Antrojoje dalyje empiriškai ịvertinamas tarptautinėse operacijose dalyvavusių Lietuvos karių kultūrinis išprusimas ir jo igijimo metodai. İvertinus tarptautinèse operacijose dalyvavusių Lietuvos karių kultūrinị išprusimą, pateikiami apibendrinimai ir rekomendacijos Lietuvos karių kultūrinio išprusimo atžvilgiu.
\end{abstract}

\section{Ivadas}

Viena pagrindinių tarptautinès operacijos „Irako laisve“" nesèkmès priežasčių buvo ta, kad vos tik pasibaigus ankstyvajai kovos fazei koalicijos pajègos suprato, kad veikia visiškai svetimoje kultūrineje aplinkoje. ${ }^{1}$ Irako kultūroje organizacinė maištininkų struktūra grindžiama šeimų ir genčių susijungimu, o visuomenès charakteristikos sukuria terpę asimetrinès karybos strategijos improvizuotųjų sprogdinimo užtaisų ir teroristų mirtininkų naudojimui. Dargi karyboje jie nesilaiko nei Ženevos konvencijos, nei neoficialių ịsipareigojimų ar taisyklių. ${ }^{2}$

Operacija „Irako laisve““ atskleidè, kad karinio konflikto sprendimas remiantis technologiniu kariuomenès pranašumu, tačiau neskiriant dèmesio karių kultūriniam išprusimui nèra efektyvus. ${ }^{3}$ Pernelyg didelio pasitikèjimo technologiniu pranašumu trūkumus taikliai apibūdino Bagdade dirbęs JAV

\footnotetext{
*Agnietė Žotkevičiūtè - Lietuvos karo akademijos Politikos mokslų katedros dèstytoja. Adresas korespondencijai: Šilo 5A, 10332 Vilnius; tel. (8 5) 210 3569; el. p. agniete.zotkeviciute@mil.lt

${ }^{1}$ Scales R., "Culture-Centric Warfare", The Naval Institute: Proceedings, U.S. Army (Retired), October 2004. Prieiga internetu: http://www.military.com/NewContent/0,13190,NI_1004_Culture-P1,00.html, 2011 2012]. ${ }^{2}$ McFate M., "Anthropology and Counterinsurgency: The Strange Story of their Curious Relationship", Military Review, March-April, 2005, p. 2438, p. 24.

${ }^{3}$ Scales R., "Army Transformation: Implications for the Future", Statement of Major General Robert Scales, USA (ret.), Testifying before the House Armed Services Committee on July 15, 2004, 2.
} 
trečiosios pėstininkų divizijos vadas, teigdamas žinojęs „, $<\ldots>$ visas vietas, kuriose buvo paslépti priešo tankai, tačiau problema buvo tai, kad mano kariai turejo kovoti su fanatikais, vaikštančiais pėsčiomis su AK-47 ir granatsvaidžiais ir šaudančiais ị mus be jokios baimès būti nušautiems. Aš turẻjau puikų situacinị supratimą, tačiau man pritrūko kultūrinio išprusimo. Dideli technologiniai gebèjimai ir neteisingas priešas". ${ }^{*}$

NATO šalių kariuomenems vis dažniau dalyvaujant stabilizacijos, taikos atstatymo, saugumo ar humanitarinèse operacijose, kurioms igyvendinti reikalingas karių gebejjimas įsitraukti ị socialinę sąveiką su kitomis kultūromis, ${ }^{5}$ igyti vietinių gyventojų paramą ir sumažinti jų paramą opozicijai, ${ }^{6}$ sèkmingas tarptautinių operacijų ígyvendinimas tampa neatsiejamas nuo karių kultūrinio išprusimo. ${ }^{7}$ Kultūrinio išprusimo pritaikymas tarptautinių operacijų metu leidžia pritraukti vietinių gyventojų paramą: suprantant svetimos šalies kultūrą vietinių vertybes, priimamų sprendimų ir elgesio motyvus, suvokiant, kaip karių žodžiai, elgesys ir veiksmai yra suprantami, interpretuojami ir vertinami vietos gyventojų, galima pelnyti jų pagarbą, pasitikejjimą ir palaikymą ${ }^{8}$ Pritraukiant vietinių gyventojų paramą dideja sèkmingo tarptautinès operacijos ịgyvendinimo galimybès, kadangi vietiniai gyventojai gali suteikti reikalingos informacijos kariams, padèti stiprinti bendradarbiavimą tarp vietos gyventojų ir karių, skatinti palaikymą karių vykdomai veiklai, ịsitraukti ị vietines saugumo iniciatyvas, galiausiai - didinti šalies vyriausybès palaikymą karių vykdomai veiklai. ${ }^{9}$ Kultūrinis išprusimas taip pat gali padèti kariams suprasti priešo motyvaciją, jo sprendimų prièmimo procesus ir vertybių sistemą, suvokti galimus elgesio modelius, atpažinti informacines operacijas ir vykdomą propagandą. ${ }^{10}$

Lietuvos dalyvavimas tarptautinèse operacijose grindžiamas pasirašytomis kolektyvinès gynybos ir saugumo sutartimis ${ }^{11}$, kurias igyvendinant iki 2015 m. gruodžio 31 d. numatyta dalyvauti trijose NATO vadovaujamose operacijose, tai - iki 200 karių ir civilių dislokuoti Afganistane, iki 5 karių ir civilių Kosove, iki 30 karių ir civilių kovos su piratavimu operacijoje „Vandenyno skydas" ir 30 karių ir civilių Europos Sąjungos vadovaujamoje kovos su piratavi-

\footnotetext{
${ }^{4}$ Israel S., Scales R., “Iraq Proves It: Military Needs Better Intel”, New York Daily News, January 7, 2004.

${ }^{5}$ Culhane E. et al., "Beyond Frontiers: The Critical Role of Cross-Cultural Competence in the Military", The Industrial-Organizational Psychologist, Volume 50 Number 1, July 2012, p. 30-37, p. 31.

${ }^{6}$ Freakley, B. C., "Cultural Awareness and Combat Power”, Infantry, Vol. 94, No. 2, March-April 2005, 2.

${ }^{7}$ Culhane E., et al, (5 išnaša), p. 30-37, p. 31-32.

${ }^{8}$ Spencer E., "Brains and Brawn: Cultural Intelligence (CQ) as the 'Tool of Choice' in the Contemporary Operating Environment”, Canadian Military Journal, Vol. 11, No. 1, 2010, p.15-23, p. 19-20.

${ }^{9}$ Ten pat, p. 20.

${ }^{10}$ Ten pat, p. 21.

${ }^{11}$ Krašto apsaugos ministerija, „Tarptautinès operacijos“, <http://kariuomene.kam.lt/lt/tarptautines_operacijos_786.html>, 02052013.
} 
mu misijoje ATALANTA. "12 Igyvendinant šiuos tarptautinius įsipareigojimus svarbu prisitaikyti prie besikeičiančio tarptautinių operacijų pobūdžio, didesnị dèmesị skiriant tarptautinėse operacijose dalyvaujančių Lietuvos karių kultūrinio išprusimo raiškos tyrimams ir kultūrinio išprusimo potencialo įvertinimui. Todèl šio straipsnio tikslas yra nustatyti, kaip ir kuo grindžiant galima įvertinti tarptautinėse operacijose dalyvaujančių karių kultūrinị išprusimą ir atskleisti tarptautinėse operacijose dalyvavusiu Lietuvos karių kultūrinio išprusimo raišką.

\section{Kultūrinio išprusimo specifika}

\subsection{Kultūrinio išprusimo kompetencijų nustatymas}

Kultūrinio išprusimo poreikis priklauso nuo karių atliekamų operacijų pobūdžio ir veikimo zonos. Šis poreikis, nors ir mažiausiu mastu, atsiranda dar kariams veikiant savo kultūrinejje aplinkoje ir didèja ịsitraukiant ị koalicinių pajègų vykdomą veiklą. Didžiausias poreikis atsiranda kariams tarptautinę operaciją vykdant kitoje kultūrineje aplinkoje. Šią kaitą atsispindi Michaelio J. McCloskey'aus „buliaus akies“ modelis (žr. 1 pav.). ${ }^{13}$

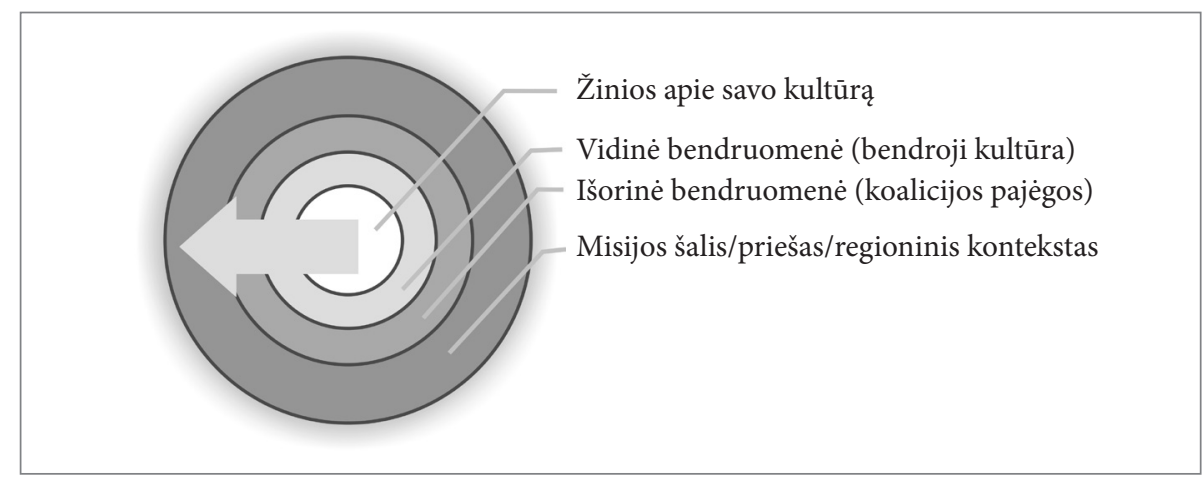

1 pav. Karių kultūrinio išprusimo poreikio modelis ${ }^{14}$

\footnotetext{
${ }^{12}$ Lietuvos Respublikos Seimas, „Dèl Lietuvos Respublikos karinių vienetų dalyvavimo tarptautinėse operacijose“, 2013 m. balandžio 23 d. Nr. XII-249, Valstybés žinios, 2013-04-27, Nr. 43-2101.

${ }^{13}$ McDonald Daniel P. et al., Developing and managing cross-cultural competence within the Department of Defense: Recommendations for learning and assessment, Paper submitted to the DLO, Revised October 27, 2008, p. 25-26.

${ }^{14}$ Šaltinis: sudaryta pagal McCloskey Michael J., Measuring Learning And Development In Army CrossCultural Competence, Draft Technical Report, Springfield, OH: 361 Interactive, LLC2008, cituota iš McDonald Daniel P. et al., Developing and Managing Cross-cultural Competence within the Department of Defense: Recommendations for Learning and Assessment, p. 25-26.
} 
Pirma vidiné modelio sfera iliustruoja, kad kariams pirmiausia ịtaka daro jų pačių kultūra, kurią suprasdami igyja potencialą suprasti ir kitą kultūrinę aplinką. ${ }^{15}$ Antrąją vidinę sferą sudaro vidinè bendruomenė (bendroji kultūra), tai civiliai ir kariai, atstovaujantys skirtingas visuomenės grupes, nors veikia savo kultūrinėje aplinkoje. Šioje sferoje susiduriama su demografiniais skirtumais ir atsiranda tarpkultūrinių kompetencijų, kurios yra svarbios norint suprasti žmogiškuosius, organizacinius ir kultūrinius skirtumus, poreikis. Pirmosios dvi vidinès modelio sferos išreiškia idèją, kad kariai turi žinoti savo kultūros vertybes ir tendencijas - taip igyjamas gebejjimas atpažinti bendravimo su kitų kultūrų atstovais panašumus ir skirtumus. ${ }^{16}$

Antra išorine modelio sfera apima kultūrinius ir organizacinius skirtumus, su kuriais kariai susiduria veikdami kitoje kultūrinèje aplinkoje. ${ }^{17}$ Ši sfera atspindi karių gebejjimą veikti kartu su tarptautiniais partneriais, pavyzdžiui, NATO šalių kariuomenėmis, kai susiduriama su skirtingomis elgesio, taktikos praktikomis ar net skirtingais tarptautinès operacijos tikslais ar tikslų siekimo būdais. ${ }^{18}$

Galiausiai, dabartinèje globalioje aplinkoje, kariuomenès įsitraukia $\mathfrak{i}$ rekonstrukcijos, humanitarines, saugumo ir kitas operacijas, kurios nèra tiesiogiai susijusios su kariniais veiksmais, o kariai kitoje kultūrinèje aplinkoje veikia ir kaip diplomatai. ${ }^{19}$ Todèl išorinè modelio sfera atspindi požiūrị, kad siekiant efektyviai veikti kitoje kultūrinèje aplinkoje ir norint suprasti šalies, kurioje vykdoma tarptautinè operacija, vietinių gyventojų vertybes, priešo motyvus ir elgesį, kariams būtina ịgyti ịvairių kompetencijų ir igūdžių, ${ }^{20}$ kurie gali būti nustatomi kaip: 1) tarpkultūrinès kompetencijos; 2) kultūros specifinès kompetencijos ir 3) kalbinès kompetencijos (žr. 2 pav.).

\footnotetext{
${ }^{15}$ Reid Patrice A., Key Perspectives on the Interplay between Cross-Cultural Competence and Diversity Competence, Defense Equal Opportunity Management Institute Directorate of Research, Technical Report Number 08-11, p. 10-11.

${ }^{16}$ Ten pat.

${ }^{17}$ Ten pat.

${ }^{18} \mathrm{McD}$ Donald Daniel P., A brief note on the multi-layered nature of cross-cultural competence. DEOMI Technical Report No. 22-08, Patrick AFB, FL: DEOMI, 2008, p. 2.

${ }^{19}$ Ten pat.

${ }^{20}$ Reid Patrice A., (15 išnaša), p. 11.
} 


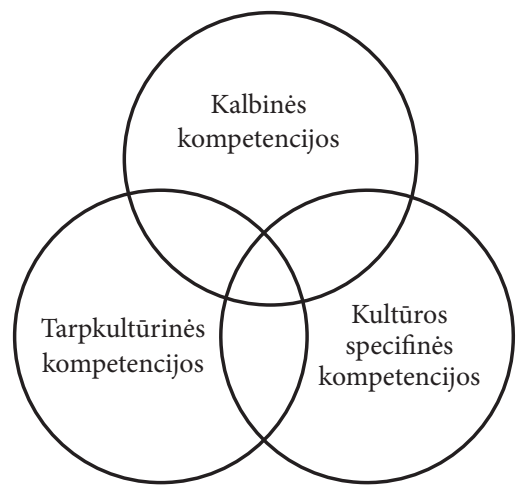

\section{2 pav. Tarptautinėse operacijose dalyvaujančių karių kultūriniam išprusimui būtinos kompetencijos ${ }^{21}$}

Šių kompetencijų tarpusavio sąveika apima visas kultūriškai išprususiam kariui reikalingas kompetencijas, atspindinčias karių žinojimą, ką galvoti, kaip galvoti, ir gebėjimą komunikuoti su šalies, kurioje vykdoma tarptautinė operacija, vietiniais.

Kultūros specifinès kompetencijos apima karių žinojimą, ka galvoti $^{22}$ ir skirstomos į: 1) žinias apie konkretų regioną ar kultūrą; 2) šių žinių pritaikymą tarptautinès operacijos metu. Kultūros specifines kompetencijas sudaro žinios apie šalies, kurioje vykdoma tarptautinè operacija ekonominę, religinę ir istorinę padètí, socialinę infrastruktūrą, vietos populiaciją, politiką, nacionalines ir religines šventes, geografinę, klimatinę, topografinę padètį. ${ }^{23}$

Tarpkultūrinès kompetencijos apima žinojimą, kaip galvoti - kaip bendrauti su kitos kultūros atstovais, kaip interpretuoti kultūriškai skirtingas situ-

\footnotetext{
${ }^{21}$ Sudaryta pagal Abbe A., Building cultural capability for full-spectrum operations, ARI Study Report 200804, Arlington, VA: U.S. Army Research Institute for the Behavioral and Social Science, 2008, p. 2.

${ }^{22}$ Ten pat, p. 2.

${ }^{23}$ Adaptuota pagal "Language, Regional Expertise, and Culture (LREC) Capability Identification, Planning, and Sourcing, Chairman of the Joint Chiefs of Staff Instruction”, CJCSI 3126.01A, 31 January 2013, p. G-1 taip pat Yee K. et al., Cultural Intelligence: Its potential for military leadership development, Paper presented at the 47th International Military Testing Association in Singapore from 8 to 10 November 2005, p. 3, taip pat Hardison Hardison Chaitra M. et al., Cross-cultural skills for deployed Air Force personnel: Defining cross-cultural performance, Santa Monica, CA: Rand Corporation, 2009, p. 66, taip pat Paris C., "Framework for Cross-Cultural Competence and Learning Recommendations", kn. Jerry C. Scarpate ir Daniel P. McDonald (sud.), Celebrating the History \& Future of Human Relations Research: DEOMI 8th Biennial Equal Opportunity, Diversity, and Culture Research Symposium, Defense Equal Opportunity Management Institute (DEOMI) Press, Patrick AFB, FL, 2012, p. 135154, p. 147 ir 2012 m. spalio 31 d. Kariuomenès vado ịsakymas Nr. V-1260 „Dèl Karių rengimo tarptautinėms operacijoms (individualių igūdžių atnaujinimo) kurso programos tvirtinimo“, p. 52-53.
} 
acijas, pritaikyti savo elgesị siekiant norimų rezultatų. ${ }^{24}$ Tai pažintiniai, elgesio ir emociniai karių ìgūdžiai ir savybès, taip pat deklaratyvios, procedūrinès ir konceptualios žinios, kritinio mąstymo igūdžiai ir socialinio įsitraukimo aspektai. ${ }^{25}$ Tarpkultūrines kompetencijas sudaro:

1) bendruju žiniu apie kita kultūra taikymas, apimantis žinias apie kitas kultūras: kaip skirtingose kultūrose suvokiami tarpasmeniniai santykiai, laikas, koks yra asmeninès erdvès poreikis, mąstymo stilius ir šios informacijos taikymą vertinant panašumus ir skirtumus tarp kultūrų;

2) organizacijos atstovavimas. atspindintis gebejimą igyvendinti atstovaujamos organizacijos (institucijos) misiją ir tikslus, sieki gerinti atstovaujamos organizacijos politiką, procedūras, programas ir praktiką, taip pat atstovaujamos organizacijos reikalavimų laikymąsi, kai susiduriama su prieštaraujančiais reikalavimais organizacijoje ir už jos ribų;

3) kitokios kultūrinès perspektyvos priemimas tai kariu supratimas, kad ju turimos kultūrinès nuostatos ir vertybès gali skirtis nuo kitų kultūrų, kitokio kultūrinio konteksto analizè ir gebejjimas ịvertinti kaip jų veiksmai ir žodžiai gali būti interpretuojami kitoje kultūrinejje aplinkoje.

4) komunikacijos igūdžiai, kuriuos sudaro žinios apie neverbalinès komunikacijos ženklus bendraujant su kitų kultūrų atstovais, priimtinų normų ir taisyklių bendraujant su kitų kultūrų atstovais žinojimas ir laikymasis, taip pat gebejjimas perduoti mintis ir idejas klausytojui priimtinu būdu;

5) tarpasmeninio bendravimo igūdžiai apima siekị ịsitraukti ì kitą kultūrinę aplinką - bendrauti ir kartu veikti su kitos kultūros atstovais ir teigiamo (kario) ịvaizdžio kitoje kultūrineje aplinkoje formavimą;

6) kultūriné adaptacija - mokejjimas pritaikyti savo elgesị ir aprangą, kai to reikia laikantis ar rodant pagarbą kitos kultūros vertybèms ar papročiams, taip pat informacijos apie kitos kultūros žmones, aplinką, priimtinas socialines taisykles ir normas rinkimas, taip gerinant bendravimo su kitais ir savo elgesio igūdžius ir gebejimas adaptuotis susiduriant su kitokių vertybių, papročių ir kultūrų žmonèmis. ${ }^{26}$

\footnotetext{
${ }^{24}$ Žr. Abbe A., Building Cultural Capability for Full-spectrum Operations, (21 išnaša), taip pat Abbe A., Halpin Stanley H., "The Cultural Imperative for Professional Military Education and Leader Development", Parameters, Winter 2010, 21-31, taip pat Selmeski B., Military cross-cultural competence: Core concepts and individual development. Royal Military College of Canada Centre for Security, Armed Forces \& Society Occasional Paper Series, Number 1, 2007.

${ }^{25}$ Culhane E. et al., (5 išnaša) p. 33.

${ }^{26}$ Adaptuota pagal Renée Y., Foundation for Diversity Training: Competency Model and Learning Objectives, Defense Equal Opportunity Management Institute, Directorate of Research, May 2011, p. 46-61, taip pat Paris C., "Framework for Cross-Cultural Competence and Learning Recommendations", p. 135-154 (23 išnaša) ir Wisecarver M. et al., Regional Expertise and Culture Proficiency. Project Report 2012-01, Defense Language and National Security Education Office, September 2012.
} 
7) Kalbinès kompetencijos - tai šalies, kurioje vykdoma tarptautinè operacija, kalbos ir (ar) kalbos, žinomos abiem atstovaujamoms pusèms (kariams ir vietiniams šalies, kurioje vykdoma tarptautinė operacija) mokejjimas. Kalbiniai igūdžiai ne tik palengvina gebẻjimą suprasti ir laikytis tam tikros kultūros elementų, bet ir leidžia ịsitraukti ị socialinę komunikaciją kitoje kultūrineje aplinkoje taip peržengiant kitos kultūros ir kultūrinių skirtumų stebėjimo ribas. ${ }^{27}$

Svarbu atkreipti dèmesĭ, kad neretai tarptautinių operacijų metu kalbos igūdžiu stygius kompensuojamas vystant per vertejus karių socialinę sąveiką su šalies vietiniais, kurioje vykdoma tarptautinè operacija. Tokiu atveju kariai turi būti paruošiami dirbti su vertẻju - naudojantis vertėjo paslaugomis, kariai turi žinoti kas gali būti sakoma, o kas nepriimtina vietiniams gyventojams; i̊sitikinti, kad verčiant vertejjas perteikia tiek žodžių prasmę, tiek tinkamą emociją, palaikyti tinkamą nežodinę sąveiką ir ịsitikinti, kad vertẻjas turi tinkamo lygio kalbos žinias, atitinkančias tarptautinès operacijos reikalavimus. ${ }^{28}$

\subsection{Kultūrinio išprusimo ịgijimo metodai}

Kultūrinis išprusimas igyjamas per ịvairią formalią ir neformalią veiklą oficialius kursus ir programas, užsièmimus klasèse, organizuojamus prieš karių vykimą ị tarptautinę operaciją, darbo patirtị, savarankišką mokymąsi ir socialinę sąveiką su šalies, kurioje vykdoma tarptautinè operacija vietiniais gyventojais ir kitais kariais. ${ }^{29}$ Dažniausiai naudojami kultūrinio išprusimo ịgijimo metodai, tai: 1) technologijomis paremtas mokymasis, 2) tradicinis mokymasis, 3) socialinis bendradarbiavimas ${ }^{30}$ ir 4 ) saviugda. ${ }^{31}$

- Technologijomis paremtas mokymasis apima nuotolinį karių mokymąsi, mokymąsi internetu, simuliacinius vaidmenų žaidimus. Šiam mokymosi metodui priskirtina ir sintetinè mokymosi aplinka - simuliaciniai videožaidimai, virtuali aplinka ir pan. ${ }^{32}$

\footnotetext{
${ }^{27}$ Watson Jeff R., The Role of Language Proficiency in Cross-cultural Competence (3C): A Fundamental Key to Intercultural Effectiveness in Military Personnel, United States Military Academy, West Point, New York, p. 3.

${ }^{28}$ Wisecarver M. et al., (26 išnaša) p. A-5.

${ }^{29}$ Ten pat.

${ }^{30}$ Caligiuri P. et al., Training, Developing, and Assessing Cross-Cultural Competence in Military Personnel. Technical Report 1284, United States Army Research Institute for the Behavioral and Social Sciences, April 2011, p. 19.

${ }^{31}$ Driel M., Assessing Organizational Cross-Cultural Competence in the Military: Developing a Measure.

Defense Equal Opportunity Management Institute, U.S.: Patrick Air Force Base, 2010, p. 28,

${ }^{32}$ Caligiuri P. et al., (30 išnaša), p. 22.
} 
- Tradiciniai mokymosi metodai apima karių užsièmimus klasėse, vaidmenų žaidimus, ịvairias diskusijas. Tradicinio mokymosi metu susipažįstama su šalies, kurioje kariai vykdys tarptautinę operaciją, kultūra. Tradiciniai mokymosi metodai gali apimti ir simuliacinius mokymosi elementus, pavyzdžiui, ị mokymus įtraukiant šalies, kurioje vykdoma tarptautinè operacija, vietinius ar mokymosi metu aptariant praktinius atvejus, grindžiamus tarpkultūriniais incidentais su kuriais jau buvo susidurta ankstesnių tarptautinių operacijų metu. Tiek tradiciniai, tiek technologijomis paremti mokymosi metodai priskirtini formaliam mokymuisi, kurị kariams suteikia ị tarptautinę operaciją juos siunčianti institucija. ${ }^{33}$

- Socialine komunikacija priskiriama neformaliam, arba - savarankiškam mokymosi metodui. Tai karių mokymasis bendraujant ir stebint kitu elgesi: kuo daugiau kariai turi tiesioginio socialinio kontakto su vietiniais šalies, kurioje vykdoma tarptautinè operacija, tuo didesné ịtaka daroma jų kultūriniam išprusimui. Taip pat svarbi ir karių socialinè komunikacija su kitais kariais ir civiliais, tiek formalioje, tiek neformalioje aplinkoje dalijantis tarptautinèse operacijose igyta patirtimi.

- Saviugda, kaip ir socialinè komunikacija, yra neformalus, savarankiškas kompetencijų igijimo būdas. Saviugda apima karių domèjimąsi knygomis apie šali, kurioje vykdys tarptautinę operaciją, internetu prieinamų šaltinių apie šalį, kurioje numatoma vykdyti tarptautinę operaciją analizę ir pan. ${ }^{34}$

Tradiciniai, technologijomis paremti mokymosi metodai ir saviugda padeda kariams igyti kompetencijų suprasti kitokią kultūrinę aplinką, o socialinė komunikacija, padeda kariams mokytis iš ịvykių ir situacijų su kuriomis jie patys ar jų kolegos susiduria tarptautinių operacijų metu. ${ }^{35}$

\footnotetext{
${ }^{33}$ Ten pat.

${ }^{34}$ Driel M., (31 išnaša), p. 30.

${ }^{35}$ Ten pat, p. 2325.
} 


\subsection{Tarptautinėse operacijose dalyvaujančių karių kultūrinio išprusimo modelis ir pagrindimas}

Atsižvelgiant ị 1.1 ir 1.2 skyriuose identifikuotas ir detalizuotas tarptautinėse operacijose dalyvaujantiems kariams reikalingas kompetencijas ir jų igijimo metodus, sudarytas tarptautinèse operacijose dalyvaujančių karių kultūrinio išprusimo modelis. Modelị sudaro dvi pagrindinès dalys: 1) tarptautinèse operacijose dalyvaujančių karių kultūriniam išprusimui reikalingos kompetencijos ir 2) tarptautinèse operacijose dalyvaujančių karių kultūriniam išprusimui reikalingų kompetencijų ịgijimo metodai. (žr. 3 pav.).

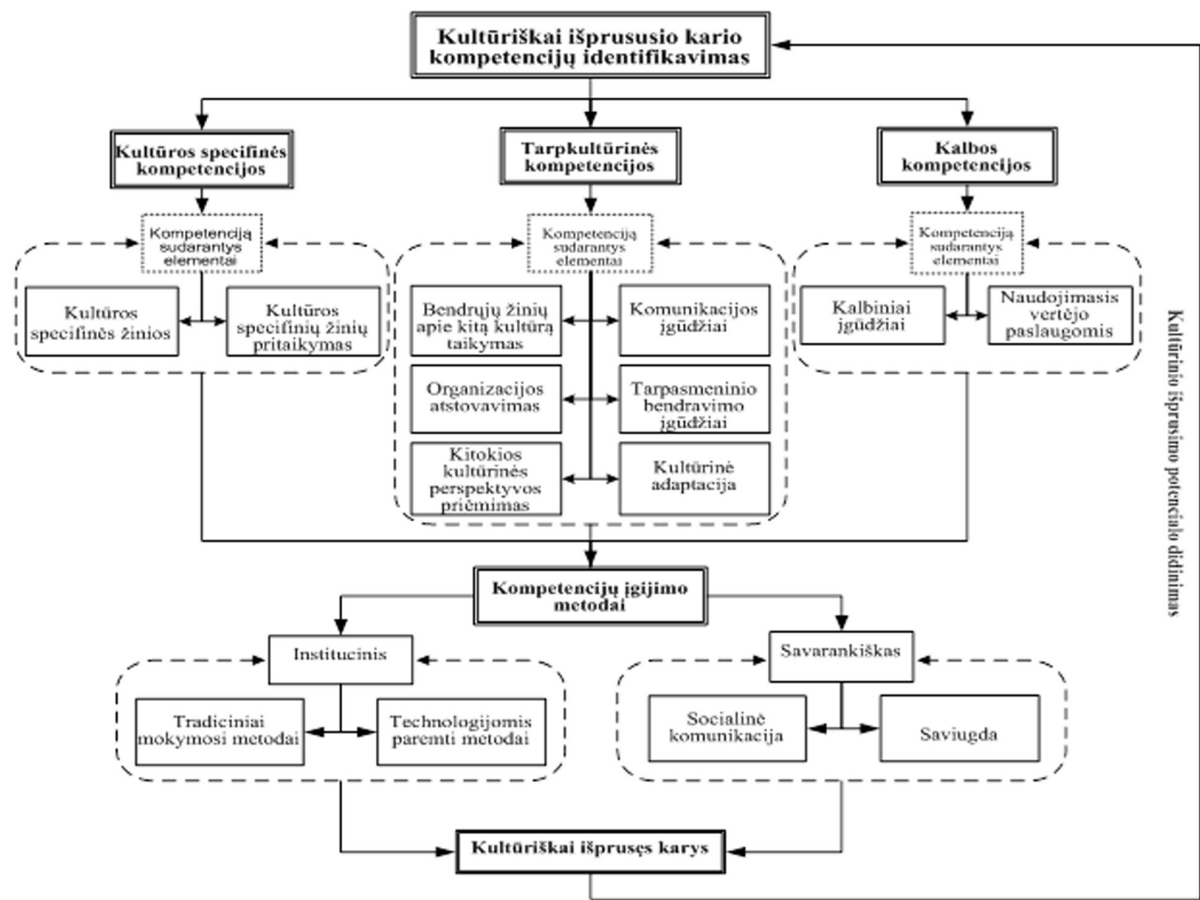

3 pav. Tarptautinèse operacijose dalyvaujančių karių kultūrinio išprusimo modelis

Remiantis šiuo modeliu, kultūriškai išprususiais laikytini kariai, turintys: 1) tarpkultūrines, 2) kultūros specifines ir 3) kalbos kompetencijas ir yra igiję jas: 1) institucinio ir (ar) 2) savarankiško mokymosi metu. Jei kariai neturi tam tikrų kompetencijų ir (ar) nesinaudoja vienu ar abiem iš minètujjų igijimo metodų, manytina, kad kariai turi potencialo didinti savo kultūrinị išprusimą. 


\section{Tarptautinèse operacijose dalyvaujančių Lietuvos karių kultūrinio išprusimo kompetencijų ir jų igijimo metodų vertinimas}

\subsection{Kultūrinio išprusimo kompetencijų ir jụ igijimo metodų tyrimo metodologija}

Tyrimu siekiama atskleisti tarptautinėse operacijose dalyvaujančių Lietuvos karių kultūrinio išprusimo raišką, tiksliau, kokios ir kiek modelyje identifikuotų kultūrinị išprusimą sudarančių kompetencijų ir jų igijimo metodų atsiskleidžia minètoje raiškoje, taip empiriškai pagrindžiant modelį, kas galiausiai leistų teigti modelio pritaikomumą tolesniems tyrimams.

Tyrimo pobūdis. Tyrimo duomenų rinkimui naudojamas pusiau struktūruoto interviu metodas, suteikiantis galimybę karių kultūrinị išprusimą interpretuoti remiantis su tiriamuoju objektu susijusių asmenų - tarptautinėse operacijose dalyvavusių karių - požiūriais ị tiriamajji objektą per karių suteikiamas prasmes. Tai leidžia atlikti giluminę tiriamojo reiškinio analizę ir išsamiai išnagrinèti esminius tarptautinèse operacijose dalyvaujančių karių kultūrinio išprusimo ypatumus.

Tyrimo procesas. Tyrimas vykdytas 2013 metų vasario ir kovo mènesiais.

Tiriamieji ir ju charakteristika. Tyrimo metu apklausta 12 karių iš ịvairių Lietuvos karinių padalinių, dalyvavusių tarptautinėse operacijose Irake, Afganistane, Kuveite, Kroatijoje ir Serbijoje. Tyrimui pasirinkti tiriamieji atitiko pagrindinį kriterijų: tirti vienoje ir daugiau tarptautinėse operacijose dalyvavę kariai. Tyrime dalyvavusių karių demografinès charakteristikos pateikiamos 1 lentelèje.

1 lentelè. Tyrime dalyvavusių karių demografinès charakteristikos

\begin{tabular}{|c|c|c|c|c|c|c|}
\hline Tiriamasis & $\begin{array}{l}\text { Karinis } \\
\text { laipsnis }\end{array}$ & $\begin{array}{c}\text { Tarnybos } \\
\text { kariuomenèje } \\
\text { trukmé } \\
\text { (metais) }\end{array}$ & $\begin{array}{c}\text { Tarptautinių } \\
\text { operacijų } \\
\text { skaičius } \\
\text { (vnt.) }\end{array}$ & $\begin{array}{c}\text { Šalys, kuriose } \\
\text { karys buvo } \\
\text { dislokuotas }\end{array}$ & $\begin{array}{l}\text { Paskutinès } \\
\text { dislokacijos } \\
\text { trukmé } \\
\text { (mèn.) }\end{array}$ & $\begin{array}{l}\text { Bendra } \\
\text { dislokaciju } \\
\text { trukmé } \\
\text { (mèn.) }\end{array}$ \\
\hline $\begin{array}{c}\text { Tiriamasis } \\
\text { nr. } 1\end{array}$ & Pulkininkas & 21 & 2 & $\begin{array}{c}\text { Kroatija ir } \\
\text { Afganistanas }\end{array}$ & 24 mèn. & 36 mèn. \\
\hline $\begin{array}{c}\text { Tiriamasis } \\
\text { nr. } 2\end{array}$ & Majoras & 18 & $\begin{array}{c}2 \text { ilgalaikès } \\
\text { ir } 3 \text { trumpa- } \\
\text { laikès }\end{array}$ & $\begin{array}{c}\text { Irakas, Af- } \\
\text { ganistanas, } \\
\text { Kuveitas }\end{array}$ & 6 mèn. & 14 mèn. \\
\hline
\end{tabular}




\begin{tabular}{ccccccc}
\hline $\begin{array}{c}\text { Tiriamasis } \\
\text { nr. } 3\end{array}$ & $\begin{array}{c}\text { Laikinas } \\
\text { majoras }\end{array}$ & 14 & 2 & Afganistanas & 7 mèn. & 14 mèn. \\
\hline $\begin{array}{c}\text { Tiriamasis } \\
\text { nr. } 4\end{array}$ & $\begin{array}{l}\text { Pulkininkas } \\
\text { leitenantas }\end{array}$ & 22 & 2 & $\begin{array}{c}\text { Afganistanas } \\
\text { ir Irakas }\end{array}$ & 6 mèn. & 12 mèn. \\
\hline $\begin{array}{c}\text { Tiriamasis } \\
\text { nr. } 5\end{array}$ & Kapitonas & 13 & 2 & Afganistanas & 6 mèn. & 12 mèn. \\
\hline $\begin{array}{c}\text { Tiriamasis } \\
\text { nr. } 6\end{array}$ & Vyr. eilinis & 5 & 1 & Afganistanas & 7 mèn. & 7 mèn. \\
\hline $\begin{array}{c}\text { Tiriamasis } \\
\text { nr. } 7\end{array}$ & Majoras & 22 & 1 & $\begin{array}{c}\text { Kroatija ir } \\
\text { Serbija }\end{array}$ & 6 mèn. & 6 mèn. \\
\hline $\begin{array}{c}\text { Tiriamasis } \\
\text { nr. } 8\end{array}$ & Majoras & 22 & 1 & Afganistanas & 6 mèn. & 6 mèn. \\
\hline $\begin{array}{c}\text { Tiriamasis } \\
\text { nr. } 9\end{array}$ & Kapitonas & 20 & 1 & Irakas & 6 mèn. & 6 mèn. \\
\hline $\begin{array}{c}\text { Tiriamasis } \\
\text { nr. } 10\end{array}$ & Kapitonas & 17 & 1 & Irakas & 6 mèn. & 6 mèn. \\
\hline $\begin{array}{c}\text { Tiriamasis } \\
\text { nr. } 11\end{array}$ & Majoras & 16 & 1 & Afganistanas & 6 mèn. & 6 mèn. \\
\hline $\begin{array}{c}\text { Tiriamasis } \\
\text { nr. } 12\end{array}$ & $\begin{array}{c}\text { Vyr. leite- } \\
\text { nantas }\end{array}$ & 4 & 1 & Afganistanas & 6 mèn. & 6 mèn. \\
\hline
\end{tabular}

\subsection{Kultūrinio išprusimo raiškos vertinimo rezultatụ analizè}

\subsubsection{Tarptautinėse operacijose dalyvaujančių karių tarpkultūrinès kompetencijos: bendrujų žinių apie kitą kultūrą taikymas}

Tiriant karių gebejimą pritaikyti žinias apie kitą kultūrą, pastebèta, kad remdamiesi savo patirtimi tarptautinių operacijų metu kariai išskiria: 1) panašumus ir 2) skirtumus tarp kultūrų, kurie, savo ruožtu, gali būti: a) keliantys diskomfortą ar b) nekeliantys. Taip pat tyrimu nustatyta, kad karių sąveikai su kita kultūra didžiausią įtaką daro jų motyvacija adaptuotis kitoje kultūrinèje aplinkoje ir stereotipinių nuostatų apie kitą kultūrą vengimas (žr. 4 pav.). 
4 pav. Bendrujjų žinių apie kitą kultūrą pritaikymo aspektai

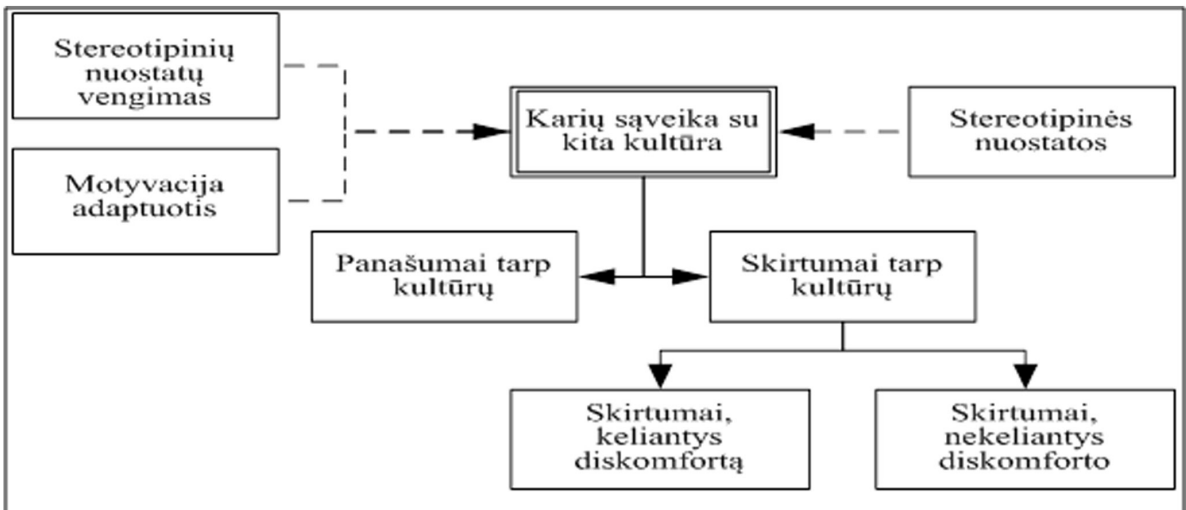

Pastaba: vientisa rodyklè ( $\longrightarrow$ )̌̌ymi kaip kariai analizuoja savo sąveiką su kita kultūra; punktyrinè rodyklè ( -..- $>$ žymi veiksnius, lemiančius karių gebẻjimą analizuoti sąveiką su kita kultūra.

Viena vertus, kariai su susiformavusiomis stereotipinėmis nuostatomis kitos kultūros atžvilgiu susiduria su panašumų ir skirtumų tarp kultūrų pažinimo stoka ir nerodo iniciatyvos analizuoti kultūrinius skirtumus:

Jeigu rimtai, tai nelabai ieškojau aš tų kultūros skirtumu. <... > Paskaitykite knygu apie indenus ir suprasite, kokie yra afganai. Jie tiesiog atsilikę nuo mūsu per kokius V amžius. " [Tiriamasis nr. 5]

Taip pat, kariams neigijus pakankamai bendrụjų žinių apie kitą kultūrą, formuojasi iškreiptas požiūris ị kitą kultūrinę aplinką:

Būti gëjumi pas juos (Afganistane) nèra taip baisu kaip pas mus. Ten, maždaug, standartas. [Tiriamasis nr. 5]

Kita vertus, turintys motyvaciją adaptuotis kitoje kultūroje (pavyzdžiui, „<...> papuolęs ị tą (kultūriškai kitokią) aplinką <...> tu nori nenori prisiderini prie jos. Aplinka niekada neprisiderins prie tavęs. Ir tik laiko klausimas, kaip greitai. Kuo greičiau prisiderini prie jos, tuo komfortabiliau jautiesi. "[Tiriamasis Nr. 9]) ir vengiantys mąstyti apie kitą kultūrą stereotipiškai (pavyzdžiui, „<... Reikia kalbetis, nes tik kalbejimasis žmonems naikina stereotipus ir tik bendravimas gali (stereotipus) sugriauti ar pataisyti." [Tiriamasis Nr. 4]), rodo iniciatyvą pažinti ir analizuoti kultūrinius skirtumus ir pritaikyti žinias apie kitą kultūrą tarptautinès operacijos metu.

Analizuodami panašumus tarp kultūrų, kariai ieško skirtingoms kultūroms būdingų bendrų sąsajų: skirtingas kultūras gretina tarpusavyje per žmonių istorinę praeiț, teigdami, kad nepriklausomai nuo kultūrinès aplin- 
kos visi žmonès turi polinkị tapatintis su savo šalies istorinėmis pergalėmis; išskiria panašias skirtingose kultūrinėse aplinkose esančių žmonių emocines išraiškas; taip pat pastebi, kad skirtingas religijas, pavyzdžiui - krikščionybę ir islamą, sieja bendras religijų pagrindas - monoteizmas.

Analizuodami skirtumus tarp kultūrų, viena vertus, dali jų kariai apibūdina neutraliai, t. y. neišskirdami dèl jų kylančio diskomforto, pavyzdžiui, teigdami, jog Irake ar Afganistane skirtingai suvokiamas autoritetas, vyrų ir moterų vaidmenys. Antra vertus, kariai išskiria skirtumus tarp kultūrų, kurie nèra toleruotini, todèl kelia diskomfortą bendraujant su vietiniais šalies, kurioje vykdoma tarptautinè operacija. Tokio pobūdžio kultūriniai skirtumai apima tarpasmeninius santykius, laiko suvokimą, asmeninès erdvės poreikį, mąstymo skirtumus ir individualumo ar kolektyviškumo suvokimą (žr. 2 lentelè).

2 lentelè. Kariụ ịvardijami diskomfortą keliantys skirtumai tarp kultūrụ

\begin{tabular}{|c|c|}
\hline Požymiai & Iliustracijos \\
\hline $\begin{array}{l}\text { Tarpasmeniniai san- } \\
\text { tykiai }\end{array}$ & $\begin{array}{l}\text { „Tai buvo labai ryšku, jei bendrauji, ̨̣eini ị kontaktą, tai jie tave priima arčiau, } \\
\text { ir tuomet tas kontaktas yra labai specifinis. Santykiuose vyras su vyru, tave } \\
\text { paima už rankos, tave vedžioja <...>. Tame bendravime yra išreiškiamas arti- } \\
\text { mas ryšys kūnu. Mums tai iššūkis, sunku persilaužti viduj." [Tiriamasis nr. 9] }\end{array}$ \\
\hline Laiko suvokimas & $\begin{array}{l}\text { „<..> Sudètinga su jais (Irake) tartis, tarkim, jei susitarei tuo laiku, tai } \\
\text { nereiškia, kad jie tuo laiku ir atvažiuos, reikia palaukti dar valanda ar dvi, } \\
\text { kada jie atvažiuos <...>. Jie atvažiuoja, viskas tvarkoj, o tu jautiesi, kad neturi } \\
\text { teisés priekaištauti." [Tiriamasis nr. 9] } \\
\text { „Didelè problema (Afganistane) suderinti bet kokị susitikima tiksliam laikui, } \\
\text { net dienai i prieki, jie nieko toliau keliu dienu i prieki neplanuoja, gyvenimas } \\
\text { pas juos - cikliškas: išgyvent šaltą žiemą, po to išgyvent karštą vasarą, ir taip } \\
\text { nuolat.“ [Tiriamasis nr. 3] }\end{array}$ \\
\hline $\begin{array}{l}\text { Asmeninès erdvès } \\
\text { poreikis }\end{array}$ & $\begin{array}{l}\text { „<...> bet jei bendrauja penkiolika centimetru nuo tavęs, tas tikrai trikdo, mes } \\
\text { norime laikytis per pusę metro, bet supranti, kad taip yra ir viskas." [Tiriamasis } \\
\text { nr. } 4 \text { ] } \\
\text { „Didesnis kolektyviškumas lemia mažesni asmeninès erdves poreiki.. Ypač } \\
\text { jaučiasi, kad laikomasi mažesnes distancijos bendraujant." [Tiriamasis nr. 6] }\end{array}$ \\
\hline $\begin{array}{l}\text { Mąstymo } \\
\text { skirtumai }\end{array}$ & $\begin{array}{l}\text { „Mąstyme jaučiasi planavimo ị priekį trūkumas, dažniausiai vadovaujamasi } \\
\text { pasakymu Insha’Allah - kaip Dievas panorès. “[Tiriamasis nr. 6] }\end{array}$ \\
\hline $\begin{array}{l}\text { Individualumo/ } \\
\text { kolektyviškumo suvo- } \\
\text { kimas }\end{array}$ & $\begin{array}{l}\text { „Lyginant ju asmenybes ir mūsu, tai mes esame individualistai. Ǎ̌ atsakau } \\
\text { už savo poelgius, o afganai ne. Jie supranta save daugiau ne kaip asmenybę, } \\
\text { o kaip šeima, gentị ir kartais tai trukdo bendraujant. Pas juos pirmiausiai } \\
\text { yra šeima, gentis, o tik paskui esi tu. “[Tiriamasis nr. 5] }\end{array}$ \\
\hline
\end{tabular}

Galima pastebèti, kad diskomfortą keliantys kultūriniai skirtumai apima socialinès sąveikos aspektus tarp karių ir vietinių šalies, kurioje vykdoma tarptautinè operacija. Kadangi su šiais skirtumais susiduriama vis labiau kariams ịsitraukiant ị kitą kultūrinę aplinką, darytina išvada, kad karių gebejjimas 
prisitaikyti prie diskomfortą keliančių kultūrinių skirtumų didina socialinès sąveikos tarp karių ir vietinių veiksmingumą, taip pat gerindamas ir visos karių vykdomos veiklos efektyvumą.

Organizacijos atstovavimas. Tiriant, kaip kariai atstovauja juos $\mathfrak{i}$ tarptautinę operaciją siunčiančią organizaciją, pastebèta, kad tiriamieji tik iš dalies sieja atstovaujamos organizacijos misijos ir tikslų iggvendinimą su dalyvavimu tarptautineje operacijoje. Tiksliau, kalbėdami apie motyvaciją dalyvauti tarptautinejje operacijoje, išskiria tris juos motyvuojančius veiksnius: 1) pareigą (darbo pobūdị); 2) finansinị atlygị ir 3) norą pažinti kitą kultūrą.

Pareiga (darbo pobūdis) kaip motyvuojantis veiksnys gali būti siejamas su organizacijos misijos ir tikslų igyvendinimu: kariai supranta savo organizacijos misiją ir funkcijas, kitaip tariant - šalies tarptautinị ịsipareigojimą, atsispindintị iggyvendinant organizacijos funkcijas.

Visgi, dalis karių dalyvauja tarptautineje operacijoje remdamiesi išimtinai asmeniniais motyvais, tokiais kaip noras pažinti kitas kultūras ir (ar) finansinis atlygis. Asmeniniais motyvais besiremiantys kariai dalyvavimo tarptautineje operacijoje netapatina su atstovaujamos organizacijos tikslų igyvendinimu, todèl, darytina prielaida, kad šiems kariams gali trūkti sąmoningumo, kad visa jų veikla tarptautinés operacijos metu remiasi atstovaujamos organizacijos misijos ir tikslų igyvendinimu. Karių motyvacijos dalyvauti tarptautineje operacijoje prielaidas iliustruoja tiriamųjų pasisakymai, pateikiami 3 lentelèje.

3 lentelè. Karių motyvacijos dalyvauti tarptautinèje operacijoje prielaidos

\begin{tabular}{|c|c|}
\hline Požymiai & Iliustracijos \\
\hline \multirow[t]{2}{*}{$\begin{array}{l}\text { Karių motyvacija dalyvauti } \\
\text { tarptautineje operacijoje, kaip } \\
\text { organizacinio sąmoningumo } \\
\text { atspindys }\end{array}$} & $\begin{array}{l}\text { Darbas toksai. Čia ne pareiga. Aš tai vadinu darbu, vis vien daug metu } \\
\text { ruošiesi, treniruojiesi, suvoki, ką tu dirbsi <...>. Sunku kai kam suvokti, } \\
\text { bet tai darbas. <...> Tu mokaisi, tu gauni proga }<\ldots>\text { padirbti realiai tą } \\
\text { darbą. [Tiriamasis nr. 2] }\end{array}$ \\
\hline & $\begin{array}{l}\text { Pirmiausia, man yra patirtis ir atsakingos pareigos, pinigai yra žemiau. } \\
\text { [Tiriamasis nr. 3] }\end{array}$ \\
\hline \multirow{3}{*}{$\begin{array}{l}\text { Karių motyvacija dalyvauti } \\
\text { tarptautineje operacijoje, kaip } \\
\text { asmeninių paskatų atspindys }\end{array}$} & $\begin{array}{l}\text { Noras pažinti kitu kultūru tautas, ieškojimas ir kelionès, ir ne tik geo- } \\
\text { grafine prasme; siekis realizuoti save. [Tiriamasis nr. 1] }\end{array}$ \\
\hline & Noras igyti naujos patirties, pažinti kultūrą. [Tiriamasis nr. 12] \\
\hline & Pinigai. [Tiriamasis nr. 5] \\
\hline
\end{tabular}

Tyrimo duomenų analizès metu išryškèjo sąveika tarp asmeninių paskatų motyvuojamų karių ir jų gebejjimo pritaikyti kultūrines žinias, galinti reikšti, kad kariai, pabrěžiantys juos išimtinai motyvuojantị veiksnị - finansinị atlygi, pasižymi didesniu stereotipiniu mąstymu kitos kultūros atžvilgiu. 
Atkreiptinas dèmesys, kad susidurdami su organizacijos biurokratinių procedūrų nepaslankumu ir ribotais finansiniais ištekliais tarptautinès operacijos metu, kariai išreiškia pasyvią poziciją organizacijos politikos, procedūrų, programų ir praktikos gerinimo atžvilgiu. Karių pozicija iliustruojama 4 lentelèje.

4 lentelè. Kariụ ìvardijamos kliūtys gerinant organizacijos veiklą

\begin{tabular}{|c|c|}
\hline Požymiai & Iliustracijos \\
\hline & $\begin{array}{l}<\ldots>\text { Blogiausia buvo su lietuviu gamybos uniformom ir batais - jie } \\
\text { tikrai prastos kokybès, todèl neretai kariai už savo pinigus pirko batus, } \\
\text { bet niekas triukšmo nekèlè, nes lietuviai kantrūs, o ir vis tiek tai nieko } \\
\text { nepakeistu, nes juk krizè. [Tiriamasis nr. 3] }\end{array}$ \\
\hline $\begin{array}{l}\text { Riboti organizacijos finansiniai } \\
\text { ištekliai }\end{array}$ & $\begin{array}{l}\text { Taigi pati žinai, kad tiek mes ir turim čia, Lietuvoj, kur kreiptis. Tie pri- } \\
\text { etaisai, kurie tau reikalingi aš žinau, kiek kainuoja <...>. Aš puikiai su- } \\
\text { vokiu kiek tai kainuoja ir kokios mano šalies galimybès. (Kaip elgètės?) } \\
\text { Naktį mažiau darai, laikaisi atsargumo priemonių. Kažkada žmonés su } \\
\text { kardais kariavo. Mūsu ginkluotè šešiasdešimtų metu lygio, grubiai Viet- } \\
\text { namo karo metų, todèl ir elgiesi atitinkamai, pasilieki didesni atstumą, } \\
\text { daugiau laiko, atsargiau. [Tiriamasis nr. 2] }\end{array}$ \\
\hline $\begin{array}{l}\text { Organizacijos biurokratinių } \\
\text { procedūrų nepaslankumas }\end{array}$ & $\begin{array}{l}<\ldots>\text { Labai dažnai kažkur kreiptis ir prašyti užtrunka, o jei man } \\
\text { reikia greitai, tai ir reikia greitai. [Tiriamasis nr. } 4 \text { ] } \\
<\ldots>\text { Mūsu (Lietuvos) biurokratinis aparatas veikia pernelyg lètai. } \\
\text { [Tiriamasis nr. 11] }\end{array}$ \\
\hline
\end{tabular}

Taip pat kariai nesilaiko savo atstovaujamos organizacijos reikalavimų, kuomet susiduriama su prieštaraujančiais reikalavimais organizacijoje ir už jos ribų. Organizacijos reikalavimų nesilaikymą kariai grindžia siekiu didinti vietinių gyventojų pasitikèjimą jais:

Pagal reikalavimus visada, büdami už savo stovyklos, privalom dèvèti šarvinę liemenę, dèvèti šalma ir büti su automatiniu ginklu rankose. Bet, ypatingai, mano padalinys, eidamas $j$ svečius pas vietos lyderius gerti arbatą, nusiimdavom viska ir pasilikdavom tik pistoleta, nes eidami su visa ekipuote rodytumèm nepasitikéjima afganu svetingumu. Tad pažeisdavom formalius saugumo reikalavimus, bet toks müsu darbas - didinti pasitikejimą vietiniu akyse. [Tiriamasis nr. 3]

Galima teigti, kad karių motyvacija dalyvauti tarptautineje operacijoje yra karių gebejjimo atstovauti organizacijai atspindys, leidžiantis karių motyvaciją susieti su tam tikra karių stereotipinių nuostatų raiška. Kiti organizacijos atstovavimo aspektai - karių siekis analizuoti, kaip galima gerinti atstovaujamos organizacijos politiką, procedūras, programas ir praktiką, ir atstovaujamos organizacijos reikalavimų laikymasis, kai susiduriama su prieštaraujančiais reikalavimais organizacijoje ir už jos ribų - iš dalies yra ribojami pačios organizacijos. Pastebimas karių pasyvumas gerinant organizacijos politiką, procedūras, programas ir praktiką tarptautinès operacijos metu sietinas su ri- 
botais organizacijos finansiniais ištekliais ir sudaromomis kliūtimis efektyviai karių veiklai tarptautinès operacijos metu.

Atstovaujamos organizacijos reikalavimų nesilaikymas tarptautinès operacijos metu, viena vertus, sietinas su paslankesnių organizacijos reikalavimų poreikiu, atsižvelgiant ị karių vykdomą veiklą. Antra vertus, nesilaikydami organizacijos reikalavimų kariai vis vien siekia organizacijos tikslų igyvendinimo pritraukiant vietinius šalies, kurioje vykdoma tarptautinè operacija.

Kitokios kultūrinès perspektyvos prièmimas. Tiriant karių gebẻjimą priimti kitokią kultūrinę perspektyvą, pastebèta, kad kariai, lygindami savo kultūrines nuostatas ir vertybes su kitomis kultūromis, geba matyti save iš kitos kultūros perspektyvos ir ịvertina stereotipinių nuostatų formavimosi pavojų:

Aišku, mes naudodavome laiko squvoka, tartis, labai blogai operacijose, kai planuojame jungtine operacija, kai operacijose susitari, o to žmogaus nèra, tada galvoji, klausimas, ar jo nèra, nes jis neatvažiavo, ar jo néra, nes jis nenori to daryti, ar jis tave pakišo, o pats pabeigo <...> ir požiūris iš karto neigiamas. <...> Jūs nepykote? Iš pradžiu pykau, paskui supratau: su europiečiu būtu tikras pyktis, bütum rimtai susipykęs. Kitas dalykas - kai tu pykstiesi su europiečiu, jis tau pyktị grą̌ina, tu irgi gauni pyktị atgal, o jie negrą̌ina, čia išeina, kad tik vienas pyksti. <...> Labai greitai formuoji nuostatas. Reikia save gaudyti, kad tos nuostatos nebütu bendros. [Tiriamasis nr. 2]

Analizuodami kaip jų veiksmai ir žodžiai gali būti suprantami kitos kultūros atstovų, kariai ịvertina institucinių mokymų metu ịgytą informaciją ir šia informacija disponuoja priklausomai nuo kitos kultūrinės aplinkos:

„(Institucinių mokymų metu) buvo pasakyta, nediskutuoti religinèm temoms. Jei man sako, nediskutuokite, tai (reiškia) nebendraukite, bet jei aš skaičiau Korana, <...> ir jei aš suprantu, kur (religijos) sueina i vieną, ar tai diskusija? Jei esi nepakankamai išprusęs - nediskutuok; jei pats esi tikintis, ir savo tikèjima išmanai - kalbèk. " [Tiriamasis nr. 4]

Taigi, galima teigti, kad didèjant karių kultūriniam išprusimui, pastebimas karių noras analizuoti savo suformuotas nuostatas kitos kultūros atžvilgiu, taip pat siekis ne tik igyti informacijos apie kitą kultūrą, bet ir šia informacija disponuoti, atsižvelgiant ị kitą kultūrinę aplinką.

Komunikacijos iggüdžiai. Tiriant karių gebejimą laikytis priimtinų normų ir taisyklių bendraujant su kitų kultūrų atstovais, išskirtinos: 1) kitos kultūros normos ir taisykles, kurių turi būti paisoma ir 2) kitos kultūros normos ir taisykles, kurių gali būti nepaisoma. Normų ir taisyklių, bendraujant su kitų kultūrų atstovais, paisymą iliustruoja tiriamųjų pasisakymai, pateikiami 5 lentelëje. 
5 lentelè. Normų ir taisyklių, bendraujant su kitų kultūrų atstovais, paisymas

\begin{tabular}{ll}
\hline Požymiai & Iliustracijos \\
\hline Kitos kultūros normos & Mums tai (maisto valgymas Ramadano šventès dienos metu) nebuvo ta \\
ir taisyklès, kurių galima & problema $<\ldots>$. Jie vis vien supranta, kad tu esi svetimšalis, bent jau Irakas \\
nepaisyti & yra modernesnè šalis, ypač miestuose, ir visiškai netaikydavo mums savo \\
& normų. [Tiriamasis nr. 2]
\end{tabular}

(Ramadano šventès metu stengtasi nevalgyti dienos metu) Nors ne prie akiu. Bent jau akivaizdžiai prie jų, bet tai nebūtų problema, net jeigu valgytume. (Nebūtų, nes) tai jų šventè, ne mūsų. Jie supranta, kad mes nepasninkaujame, kad mes ne musulmonai, ir lyg ir neprivalome laikytis ju papročių <...> [Tiriamasis nr. 4]

Vietiniai mažiau akcentavo ịvairius kultūrinius ypatumus, pavyzdžiui, einant i namus nusiauti batus, iškelto nykščio rodymas, nei tai buvo daryta mokymu metu. [Tiriamasis nr. 6]

Kitos kultūros normos ir taisyklès, kurių turi būti Ypač daug nesusipratimu kildavo Ramadano laikotarpiu, stengdavaisi paisoma demonstratyviai nevalgyti ir negerti šalia musulmonų. [Tiriamasis nr. 8]

Tabu buvo kišimasis i jų gyvenimą, jei eisi i namus, i ju gyvenima kišiesi. Jei būdavo operacijos, tai jie (vietiniai) pirmiausia eina, tu eini iš paskos. Jei patrulis eini per jų kiemą, tai piktais veidais žiūri. [Tiriamasis nr. 2]

Vertindami kitos kultūros normas ir taisykles, kurių turi būti paisoma ir kurių galima nepaisyti, kariai sektinu pavyzdžiui pasirenka šalies, kurioje vykdoma tarptautinè operacija, vietinių gyventojų požiūrị i jų elgesị ir veiksmus. Pastebima, kad tam tikras normas ir taisykles, pavyzdžiui, maisto valgymą Ramadano šventės dienos metu, kariai priskiria tiek prie normų ir taisyklių, kurių turi būti paisoma, tiek prie normų ir taisyklių, kurių gali būti nepaisoma. Toks kitos kultūros normų ir taisyklių skirstymas yra subjektyvus, todèl itin svarbu skatinti karių siekị įsitraukti ị socialinę sąveiką su šalies, kurioje vykdoma tarptautiné operacija, vietiniais gyventojais, kadangi socialinė sąveika leidžia įvertinti tikètinas vietinių gyventojų reakcijas ị vienų ar kitų normų ar taisyklių paisymo svarbą tam tikroje kultūrineje aplinkoje.

Tarpasmeninio bendravimo igūužiai. Analizuojant tarptautinèse operacijose dalyvavusių karių gebejimą bendrauti ir veikti kartu su kitos kultūros atstovais, dažniausi karių ịsitraukimo ỉ kitą kultūrinę aplinką motyvai yra: 1) įsitraukimas, kaip pareiga, ir 2) ̨̇sitraukimas, kaip adaptacijos kitoje kultūroje siekis (žr. 6 lentelè). 
6 lentelè. Karių gebèjimas bendrauti ir veikti kartu su kitos kultūros atstovais

\begin{tabular}{|c|c|}
\hline Požymiai & Iliustracijos \\
\hline Itsitraukimas, kaip pareiga & $\begin{array}{l}\text { Abiejose misijose buvau civiliu ir kariu bendradarbiavimo grupés narys } \\
\text { - mano pareiga nuolat bendrauti su vietiniais ir su jais vykdyti bendrus } \\
\text { projektus. [Tiriamasis nr. 3] }\end{array}$ \\
\hline \multirow[t]{2}{*}{$\begin{array}{l}\text { Isitraukimas, kaip adaptacija } \\
\text { kitoje kultūrinèje aplinkoje }\end{array}$} & $\begin{array}{l}\text { Stengiuosi gerbti ir laikytis papročių, jei nežinau, pasiteirauju, kaip elgtis. } \\
\text { [Tiriamasis nr. 1] }\end{array}$ \\
\hline & $\begin{array}{l}\text { Jeigu jam (vietiniam žmogui) nepriimtina tai, ka aš darau, tai aš neda- } \\
\text { rau, tai ju papročiai, jei aš pradesiu žmogu mokyti elgtis pagal tai, kaip } \\
\text { man atrodo teisinga, kaip reikia, aš esu svečias, tai jo taisyklès galioja, ne } \\
\text { mano, jei jie kažka švenčia, ir jiems tuo metu reikalinga šeimyninè diena, } \\
\text { tai jie ir gauna ta šeimyninę šventę. [Tiriamasis nr. 4] }\end{array}$ \\
\hline
\end{tabular}

İsitraukimas, kaip pareiga, sietinas su karių darbo pobūdžiu - kariai supranta, kad vykdo savo atstovaujamos organizacijos misiją ir tikslus, todèl nepriklausomai nuo to ar turi siekị teigiamai pristatyti save kitoje kultūrinèje aplinkoje, kariai geba prisitaikyti bendraudami ir dirbdami kartu su šalies, kurioje vykdoma tarptautinė operacija, vietiniais.

İsitraukimas, kaip adaptacija, atspindi karių siekị teigiamai pristatyti save kitoje kultūrinèje aplinkoje ir gebejimą pritaikyti savo idejas ir elgesị siekiant kompromiso bendraujant su šalies, kurioje vykdoma tarptautiné operacija, vietiniais.

Nenorejimas ir (ar) negebejimas ịsitraukti sietinas su karių suformuotomis stereotipinemis nuostatomis:

Bendravimas su tokiais žmonèmis gali būti tik galios santykiais paremtas bendravimas. Jie turi jausti, kad esi viršum jų. [Tiriamasis nr. 8]

Jie yra kvaili, juos galima lengvai kontroliuoti, jei igauni ju pasitikèjima. [Tiriamasis nr. 5]

Stereotipines nuostatas turintys kariai nejaučia poreikio įsitraukti $\mathfrak{i}$ bendravimą su kitos kultūros atstovais. Tai ne tik mažina karių veiklos kitoje kultūrineje aplinkoje veiksmingumą, bet ir atspindi, kad kariai galimai savo vykdomos veiklos nesieja su pareiga igyvendinti atstovaujamos organizacijos misiją ir tikslus.

Kultūrine adaptacija. Pagrindiniai tyrimo metu išryškėję karių kultūrinès adaptacijos aspektai, tai: 1) aplinkos stebèjimas, 2) socialinè komunikacija, 3) supratimas, kad karys yra svečias, 4) pagarba vietiniams gyventojams ir jų vertybėms. Karių išskiriamus adaptacijos aspektus iliustruoja tiriamųjų pasisakymai, pateikiami 7 lentelëje. 
7 lentelè. Karių kultūrinę adaptaciją sudarantys aspektai

\begin{tabular}{|c|c|}
\hline Požymiai & Iliustracijos \\
\hline Aplinkos stebejjimas & $\begin{array}{l}<\ldots>\text { Jie puikiai žino derèjimosi proceso psichologiją, reikèdavo (elgtis) labai } \\
\text { atsargiai, nes jausdavai, kad tu turi tarti paskutinǐždį, kad taip, aš pažadu. } \\
\text { Nes taip jie gražiai su tavimi bendrauja, kad supranti kad jau esi ant tos } \\
\text { ribos kai turi pažadèti, bet turi büti labai atsargus, nes jeigu neišpildysi - } \\
\text { pakenksi santykiams ir gali prarasti autoriteta. Nes autoritetas jiems labai } \\
\text { svarbus bendravime. Ir autoriteto išsikovojimas, užsitarnavimas yra tam } \\
\text { tikras procesas. Jie turi pasitikèti tavimi." [Tiriamasis nr. 9] }\end{array}$ \\
\hline Socialinè komunikacija & $\begin{array}{l}<\ldots>\text { Bandète paragauti jų maisto iš mandagumo? Tekdavo, bet iš karto po } \\
\text { to vaistai ir viskas. Labai stengdavomés privengti, bet jeigu tu eini } i \text { dery- } \\
\text { bas, ar ị apklausas, nori kažką išgauti tu jau pasiruošęs savo skrandį, bet } \\
\text { paskui vaistai }<\ldots>\text {. "[Tiriamasis nr. 2] }\end{array}$ \\
\hline \multirow{2}{*}{$\begin{array}{l}\text { Supratimas, kad karys yra } \\
\text { svečias }\end{array}$} & $<\ldots>$ aš esu svečias, tai jo taisykles galioja, ne mano $<\ldots>$. [Tiriamasis nr. 4] \\
\hline & $\begin{array}{l}\text { Taikiausi prie jų, nes su jais bendravimas vyko bazés išorèje, ju teritorijo- } \\
\text { je. Ju teritorijoje negali jų nervuoti, nes esi karinių veiksmu zonoje, negali } \\
\text { pradèti nenormaliai elgtis, negali pradèti įvedinèti savo tvarkos, drausmés. } \\
\text { Natūralu, tu esi su jais, vedi pratybas, tai deriniesi prie jų. [Tiriamasis nr. 9] }\end{array}$ \\
\hline $\begin{array}{l}\text { Pagarba vietiniams gyven- } \\
\text { tojams ir jų vertybems }\end{array}$ & $\begin{array}{l}<\ldots>\text { aš niekada neduosiu velniug girdint jo (vietinio žmogaus) pavaldiniams } \\
<\ldots>\text {. Gerbdamas ji aš kalbèsiu tik jam apie padarytus ir nepadarytus } \\
\text { darbus, aš ta suprasdamas, pas juos yra aiškus garbes suvokimas: jei tu } \\
\text { padarei klaida, mes mokam patys save nuplakti, <...> (Irake), gedos ir } \\
\text { kaltès jausmas yra tapatinamas: tu nekaltas dèl to, kol tavęs nepagavo, o } \\
\text { jei pagavo, tai jau gèda. Norint draugauti geriau rodyti klaidas asmeniškai, } \\
\text { išsaugant garbę ir orumą. [Tiriamasis nr. } 4 \text { ] }\end{array}$ \\
\hline
\end{tabular}

Visi minètieji kultūrinę adaptaciją sudarantys aspektai svarbūs karių kultūriniam išprusimui. Aplinkos stebejjimo ir socialinès komunikacijos svarba atsiskleide analizuojant karių gebejjimą suprasti kitokią kultūrinę aplinką, likusieji trys aspektai - supratimas, kad karys yra svečias, pagarba vietiniams gyventojams ir jų vertybèms ir gebejjimas rasti sprendimus dviprasmiškose situacijose leidžia išplèsti karių kultūrinio išprusimo, kaip adaptacijos kitoje kultūrinëje aplinkoje, suvokimą. Todèl tai suteikia galimybę tolesniuose tyrimuose išsamiau ịvertinti karių kultūrinio išprusimo potencialą.

\subsubsection{Tarptautinèse operacijose dalyvaujančių karių žinios apie kitos kultūros specifinius bruožus}

Duomenų analizé atskleidè karių neigiamas nuostatas vertinant institucinių mokymų metu igytas žinias apie kitos kultūros specifinius bruožus (žr. 8 lentelè). 
8 lentelè. Karių nuostatos vertinant kultūros specifines žinias

\begin{tabular}{|c|c|}
\hline Požymiai & Iliustracijos \\
\hline \multirow{2}{*}{$\begin{array}{l}\text { Kultūros specifinès } \\
\text { žinios, igyjamos insti- } \\
\text { tucinio mokymo metu, } \\
\text { nèra pakankamos }\end{array}$} & $\begin{array}{l}\text { Techninis žinojimas geografijos jis nieko neduoda, jei aš žinau, kad vyksta } \\
\text { tokia ar tokia šventè, ten reikia žinoti, kodèl ji atsirado, kodèl jie tai vertina, } \\
\text { kodèl jų vertybių skalè yra truputèli kitokia. [Tiriamasis nr. 4] }\end{array}$ \\
\hline & $\begin{array}{l}\text { Pavyzdžiui aš žinau, kad yra Ramadanas, tai nelysk prie jų. Bet jei tu gali } \\
\text { kalbètis apie tai - apie tą šventę, visq esmę labai svarbus dalykas.<...> Ir } \\
\text { dabar dar sudètingas reikalas (mokymai) pas mus, sunkiai perprastas. Nes } \\
\text { važiuoja iš esmés pusmečiui, tǔ švenčių nèra daug, tad bent specifines šventes } \\
\text { tikrai galètų (mokymų metu) apibüdinti, nes jiems tai labai svarbu. [Tiria- } \\
\text { masis nr. 2] }\end{array}$ \\
\hline $\begin{array}{l}\text { Kultūros specifinès } \\
\text { žinios, tgyjamos insti- } \\
\text { tucinio mokymo metu, } \\
\text { yra subjektyvios }\end{array}$ & $\begin{array}{l}\text { (Žinias turẻjau) tik pagrindines, prieš važiuodamas domiesi istorija, geo- } \\
\text { grafija }<\ldots>\text { Kai kalbiesi su vietiniais, ̨̇vairiai jie patys vertina (istoriją). Mes } \\
\text { atvažiuojame, mes vienaip suprantame, ju žmonès sako, kad kitaip. [Tiria- } \\
\text { masis nr. 2] }\end{array}$ \\
\hline $\begin{array}{l}\text { Kultūros specifinès } \\
\text { žinios, ịgyjamos insti- } \\
\text { tucinio mokymo metu, } \\
\text { neatitinka karių darbo } \\
\text { pobūdžio }\end{array}$ & $\begin{array}{l}\text { Pasiruošimo metu buvau bendroje grupèje, kurioje buvo ruošiami kariai į } \\
\text { Afganistana ir Iraką. I Iraka buvau ruošiamas aš vienas, tai visas pristaty- } \\
\text { mas, visas ruošimas buvo Afganistano pagrindu. Nieko negavau, jokios infor- } \\
\text { macijos apie Iraką oficialiai. [Tiriamasis nr. 9] }\end{array}$ \\
\hline
\end{tabular}

Analizuodami ịgytas žinias kariai pabrèžia tuos kitai kultūrai būdingus specifinius bruožus su kuriais nebuvo supažindinti institucinių mokymų metu ir šiu žinių pritrūko įsitraukiant ị socialinę komunikaciją su vietiniais. Pavyzdžiui, teigdami, kad pritrūko žinių apie šalies, kurioje vykdoma tarptautinẻ operacija, istoriją, kaip tos šalies istoriją supranta vietiniai gyventojai, taip pat išsamesnių žinių apie jų išpažịstamą religiją.

Taip pat pastebèta, kad institucinių mokymų metu ne visada diferencijuojamas karių paruošimas skirtingoms tarptautinèms operacijoms - skirtingos kultūros gretinamos tarpusavyje, pavyzdžiui, tokie patys instituciniai mokymai organizuojami tiek kariams, vykstantiems ị Afganistaną, tiek kariams, vykstantiems ị Iraką. Tai lemia kultūrinio išprusimo potencialo mažèjimą - kariai neịgyja pakankamai žinių apie kitai kultūrai būdingus specifinius bruožus.

Kariu turimu žiniu apie kitos kultūros specifinius bruožus pritaikymas tarptautinés operacijos metu. Analizuojant, kaip kariai, būdami kitoje kultūrinëje aplinkoje pritaiko žinias apie kitą kultūrą, paaiškejjo, kad net tie kariai, kurie teigè turèję pakankamai žinių apie kitą kultūrą, vis vien atsidurdavo dviprasmiškose situacijose dèl šių žinių stygiaus:

(Dviprasmiškoje situacijoje buvau) įteikiant motocikla vietiniam departamentui spaudžiant dešinę ranką, motociklo rakteliam paduoti liko tik kairè ranka (kuri laikoma nešvaria), todèl darant nuotrauka departamento vadovas rakteliu neémè ir paème tik po to, kai padarius nuotrauką raktelius padaviau dešine ranka. [Tiriamasis nr. 6] 
Lankydamasis mokykloje fotografavau mokinius ir mokytojus, kas yra iprasta, bet vienoje mokykloje kelios mokytojos buvo jaunos, todel joms pasirode, kad jas fotografuoju specialiai. Buvau paprašytas to nedaryti <...>. [Tiriamasis nr. 3]

Karių igytos žinios apie kitos kultūros specifinius bruožus nèra pakankamos karių vykdomai veiklai tarptautinès operacijos metu, todèl institucinių mokymų metu svarbu atkreipti dèmesi i kitos kultūros specifinius bruožus, kurių pritaikymas leistų kariams išvengti dviprasmiškų situacijų bendraujant ir veikiant kitoje kultūrinèje aplinkoje. Šių žinių igijimas kartu su ugdomais karių gebejjimais analizuoti kitokị kultūrinị kontekstą ir interpretuoti mokymų metu igytą informaciją leistų kariams geriau prisitaikyti kitoje kultūrineje aplinkoje.

\subsubsection{Tarptautinèse operacijose dalyvaujančių karių kalbinès kompetencijos.}

Pagrindiniai šalies, kurioje vykdoma tarptautinè operacija, kalbos mokejjimo privalumai: 1) geresnis ryšys su pašnekovu ir 2) mandagumo, pagarbos vietiniams gyventojams išraiška (žr. 9 lentelè).

\section{9 lentelè. Kalbos ịtaka karių veiklai kitoje kultūrinèje aplinkoje}

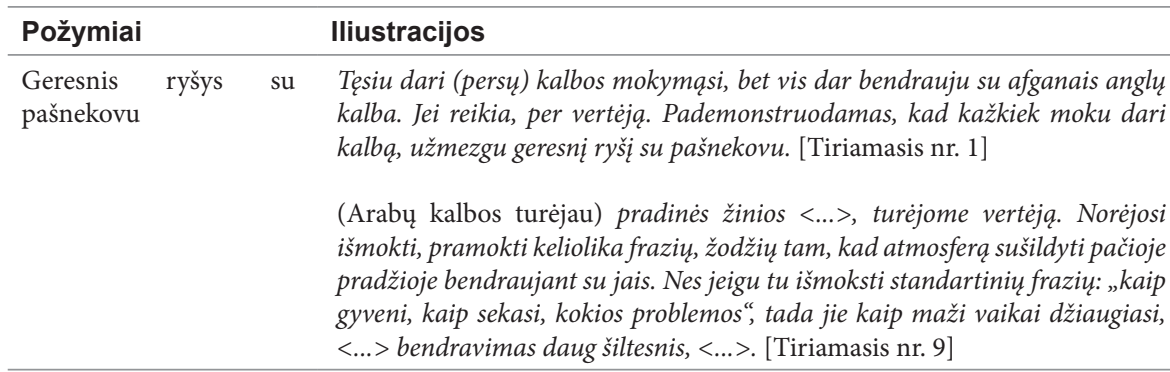

mandagumo, pagarbos vietiniams gyventojams išraiška
(Su vietiniais šalies, kurioje vykdoma tarptautinė operacija, žmonėmis bendravau) arabų, anglų, maišyta (kalba). Jie dauguma supranta anglu, dar kai kurie, senesni, moka rusiškai. Arabu tai iš mandagumo - pasisveikinimus, skaičius gali pasakyti. <...> Jei ko klausdavo, mes stengdavomés atsakyti arabiškai $<\ldots>$. [Tiriamasis nr. 2]

„(Su vietiniais žmonėmis bendravau) anglu kalba. Arabiškai aš mokejjau tik 20 ar 30 žodžių. Yra žmoniu, kurie pakankamai (gerai) kalba angliškai, su jais galima kalbèti tiesiogiai, o tie, su kuriais reikia vertejo, jie jaučiasi pažeminti, kad vertejas reikalingas, jau jis (laiko save, kad yra) neišprusęs, reikalinga tarpine grandis. Jei vertejas nesupranta klausimo esmès ir bando išsiaiškinti, jau nevienodai padalija dèmesio, gaunasi, kad vertèjas daugiau su manimi bendrauja, tai vertejas gaunasi kaltas, kad per ilgai kalbasi su manimi, tai teko nutraukti keletą kartu, kad nekiltų konfliktas <...>. [Tiriamasis nr. 4] 
Kalbos mokèjimas gerina tarptautinėse operacijose dalyvaujančių karių tarpkultūrinių kompetencijų raišką, kadangi leidžia didinti socialinès komunikacijos tarp tarptautinèje operacijoje dalyvaujančių karių ir vietinių šalies, kurioje vykdoma tarptautinè operacija, galimybes.

Naudojimasis vertẻjo paslaugomis, karių teigimu, iš dalies apsunkina jų veiklą kitoje kultūrinejje aplinkoje, nes susiduriama su 1) skirtingų kultūrų atstovų bendravimo skirtumais, 2) sunkumu perduoti emocijas, 3) vertėjų kompetencijų stygiumi, 4) vietinių gyventojų noro ịsitraukti ị bendravimą stygiumi (žr. 10 lentelè).

10 lentelè. Naudojimosi vertèjo paslaugomis įtaka karių veiklai kitoje kultūrinèje aplinkoje

\begin{tabular}{|c|c|}
\hline Požymiai & Iliustracijos \\
\hline \multirow[t]{3}{*}{$\begin{array}{l}\text { Susiduriama su } \\
\text { skirtingų kultūrų } \\
\text { atstovų bendravimo } \\
\text { skirtumais }\end{array}$} & $\begin{array}{l}\text { Vertejjas kalba multiplikuota kalba, kaip pasakas seka, yra buvę situaciju, } \\
\text { kai turi atvažiuoti taikinys, sako, kad atvažiuos juoda balta Toyota. Sẻdi } \\
\text { žmogus pozicijoje, laukia tos mašinos, o danas vertèjas sako: „ne, jis ne } \\
\text { taip pasakė, jis pasakè juoda Toyota“, tai mes sakom: „stop stop“, nes jau } \\
\text { signalas perduotas ir jei atvažiuos tas žmogus, jis bus pagautas, jis bus } \\
\text { sunaikintas ir nušautas. }\end{array}$ \\
\hline & $\begin{array}{l}\text { O jis sako, kad pilka Toyota, labiau i juodą. Čia jau kultūriškai. Pas mus } \\
\text { vakaras, tai sakome „susitinkame vakare, devintą valanda“, o jie sakytu, } \\
\text { pavyzdžiui, ypač kaimiškose vietovèse, „susitinkame vakare, kai mènulis } \\
\text { nebus pasiekęs žemès. [Tiriamasis nr. 2] }\end{array}$ \\
\hline & $\begin{array}{l}<\ldots>\text { Geras vertèjas yra tas kuris ne tik moka versti, bet tas kuris moka } \\
\text { sujungti abi kultūras } \text { i vieną. [Tiriamasis nr. 10] }\end{array}$ \\
\hline $\begin{array}{l}\text { Susiduriama su } \\
\text { sunkumu perduoti } \\
\text { emocijas }\end{array}$ & $\begin{array}{l}\text { Per vertëja šnekejimas yra tam tikra technika ir tu nežinai, kaip jis } \\
\text { išverčia, nes vertèjas yra tas pats irakietis. Tu nežinai kaip jis išverčia tavo } \\
\text { žodžius jiems, nes viskas priklauso nuo intonacijos, kaip parinkti žodžiai. } \\
\text { Aišku visa laiką stebedavau ju veidus, kurie padedavo suprasti ar ta pati } \\
\text { reakcija, kurios tu lauki savo žodžius pasakęs. Jei matai, kad nesulauki tos } \\
\text { reakcijos, tai bandai pakartoti, dar karta, paprašai vertejo, kad pasakytu } \\
\text { kitaip. Matosi galutinis korespondentas, kuris gauna ta informacija, kaip } \\
\text { jis reaguoja ị tą informaciją. [Tiriamasis nr. 9] }\end{array}$ \\
\hline $\begin{array}{l}\text { Susiduriama su } \\
\text { vertejų kompetencijų } \\
\text { stygiumi }\end{array}$ & $\begin{array}{l}\text { Ne visi vertėjai kompetentingai verčia, ilgai trunka pats vertimo procesas, } \\
\text { vietiniai gyventojai nesilaiko bendravimo kultūros - pertraukia, nuolat } \\
\text { kalba mobiliuoju telefonu per susitikimus, nèra mandagūs. [Tiriamasis } \\
\text { nr. 3] }\end{array}$ \\
\hline $\begin{array}{l}\text { Susiduriama su } \\
\text { vietinių gyventojų } \\
\text { noro įsitraukti } \underset{t}{ } \\
\text { bendravimą stygiumi }\end{array}$ & $\begin{array}{l}<\ldots>\text { Pašnekovas dažnai nesilaiko bendravimo per vertèja taisykliu - } \\
\text { kalbèdamas žiūri i vertëja, kalba per ilgai, kai kuriuos dalykus adresuoja } \\
\text { vertėjui. [Tiriamasis nr. 6] }\end{array}$ \\
\hline
\end{tabular}

Naudojimąsi vertejjo paslaugomis galima įvardinti kaip apsunkinantị karių adaptaciją kitoje kultūrinèje aplinkoje veiksnį, nes mažèja ịsitraukimo ị efektyvią socialinę komunikaciją galimybès. Vis gi, naudojimasis vertėjo paslaugomis gali padèti kompensuoti karių kalbinių igūdžių stygių ịsitraukiant 
ì socialinę komunikaciją. Todèl kariai turi būti supažindinami su galimomis kliūtimis bendraujant per vertèją ir mokomi kaip mažinti šių kliūčuu raišką ịsitraukiant ị socialinę sąveiką.

Kultūrinio išprusimo kompetenciju igijimo metodai. Tiriant kultūrinio išprusimo kompetencijų igijimo metodus, galima išskirti: 1) institucinị ir 2) savarankišką kompetencijų igijimą.

Krašto apsaugos sistemos organizuojami instituciniai mokymai apima tiek tradicinius mokymosi metodus (pavyzdžiui, „Buvo pasirengimo ciklas, $k u$ rios metu buvo nagrinejama tos šalies kultūra. " [Tiriamasis nr. 10]), tiek technologijomis paremtus metodus (pavyzdžiui, „Prieš misiją mano skyriaus kariai privalejjo baigti keletą kursu nuotoliu būdu apie Afganistana, istoriją, kultūra ir pan. Taip pat kiekvienas privalejom baigti minimum po viena normalu kursa Lietuvoj ar užsienyje, susijusị su mūsų skyriaus veikla." [Tiriamasis nr. 3]).

Institucinius mokymus kariai vertina skeptiškai, pabrèždami, kad tai tik privalomi, formalūs mokymai:

(Instituciniai mokymai) 50 proc. naudingi, o 50 proc. užsidèti pliusą, kad jeigu kas nors žus, atsakyti i klausima ,ar buvo mokyta?". Ir 50 proc. dar labai optimistiškai (vertinant). [Tiriamasis nr. 2]

Kaip vieną naudingiausių mokymosi metodų kariai įvardija patirtị šalyje, kurioje vykdoma tarptautinė operacija:

„Kiek daug besimokysi teoriškai, tegul ir praktiškai - bet kitoje kultürinèje aplinkoje, niekada visko nesužinosi. Svarbu, kad mūsu kariams būtu pasakoma, kad realybè bus gana skirtinga, netikètumu bus daug <...>. [Tiriamasis nr. 1]

$<\ldots$. niekada parengimas negali büti (pakankamas), kol tu nenuvažiuoji ir nepamatai krašto. [Tiriamasis nr. 4 ]

Visgi, neturedami pakankamo kultūrinio pasirengimo tarptautinès operacijos metu kariai negali veiksmingai veikti kitoje kultūrinejje aplinkoje, kadangi yra labiau orientuoti ị mokymąsi apie kitą kultūrą stebint aplinką, tačiau dèl kompetencijų stygiaus nę̧sitraukiant ị socialinę sąveiką su vietiniais:

Pirmoji misija yra pasirengimas antrajai, tai jei aš važiuočiau trečia kartą, tai noréčiau, kad tai bütų ne tik islamiškas, bet ir arabiškai kalbantis kraštas dèl to, kad viską, ka aš gavau per pirmas dvi keliones, man praverstu trečioje. Jei aš važiuočiau ne ị islamišką kraštą, tai man tektų mokytis viska iš nulio. <...> Antros (tarptautinès operacijos metu) veiksmas buvo labai su vietiniais, patarejo darbas, o pirmos misijos metu turëjau kovines užduotis, kurios nereikalavo kasdieninio bendravimo su vietiniais. Jeigu būtų buvę atvirkščiai, tai tada aš sakyčiau nebūčiau buvęs pasiruošęs tinkamai. [Tiriamasis nr. 4] 
Analizuodami, kaip galima gerinti institucinio mokymosi kokybę, kariai išskiria pagrindinius tobulintinus aspektus: 1) i mokymus itraukti instruktorius, buvusius šalyje, kurioje vykdoma tarptautinè operacija ir (ar) instruktorius, kilusius iš šalies, kurioje vykdoma tarptautinè operacija, 2) vykdyti antropologijos studijas; 3) mokymus pritaikyti tikslinei auditorijai ir 4) gerinti karių užsienio kalbos igūdžius (žr. 11 lentelè).

\section{1 lentelè. Institucinių mokymų tobulinimo galimybès ruošiant karius tarptautinèms operacijoms}

\begin{tabular}{|c|c|}
\hline Požymiai & Iliustracijos \\
\hline $\begin{array}{l}\text { Ittraukti instruktorius, } \\
\text { buvusius šalyje, kurioje } \\
\text { vykdoma tarptautinė } \\
\text { operacija, arba in- } \\
\text { struktorius, kilusius iš } \\
\text { šalies, kurioje vykdoma } \\
\text { tarptautinè operacija }\end{array}$ & $\begin{array}{l}\text { Mokytojai, instruktoriai turi būti geriausi iš geriausių, būtinai buvę operaci- } \\
\text { jose. Jei operacija nauja - dalyvavę panašiose operacijose. [Tiriamasis nr. 1] } \\
\text { I mokymus ịtraukti instruktorius, kilusius iš šalies, kurioje vyksta } \\
\text { tarptautine operacija. [Tiriamasis nr. 6] }\end{array}$ \\
\hline $\begin{array}{l}\text { Vykdyti antropologijos } \\
\text { studijas }\end{array}$ & $\begin{array}{l}<\ldots>\text { Mes nemokame mokytis kultūros ir suprasti jos. Ir nuo pat kariūno } \\
\text { rengimo, jiems šitas dalykas turi büti suprantamas }<\ldots>\text { kadangi jau daug } \\
\text { metu esame tarptautinèje aplinkoje. [Tiriamasis nr. 2] }\end{array}$ \\
\hline $\begin{array}{l}\text { Mokymus pritaikyti } \\
\text { tikslinei auditorijai }\end{array}$ & $\begin{array}{l}\text { „Pagrindinis dalykas }<\ldots>\text { auditorijos pritaikymas, pagal tikslinę auditoriją. } \\
\text { Nesvarbu vienas ar du (kariai) ruošiami ten dirbti, bet jiems ir turi büti } \\
\text { sukurtas mokymo procesas pagal tą vieta i kuria važiuoja. Tuo labiau, } \\
\text { kad iš tos vietos grižta tie kariai, kurie ten buve ir jie puikiai gali pateikti } \\
\text { informaciją apie tą šalị ir tu ten nuvažiavęs <....> [Tiriamasis nr. 9] } \\
\text { Akcentuoti į atskira funkciniu specialistu rengimą. "[Tiriamasis Nr. 12] }\end{array}$ \\
\hline $\begin{array}{l}\text { Gerinti karių užsienio } \\
\text { kalbos igūdžius }\end{array}$ & $\begin{array}{l}\text { Norètųsi daugiau mokèti vietos kalbos fraziu, nes pasirengimo metu trūko } \\
\text { laiko ilgiau mokytis vietos kalbos. [Tiriamasis nr. 3] }\end{array}$ \\
\hline
\end{tabular}

Viena vertus, suvokdami tobulintinas institucinių mokymų sritis, kariai nerodo siekio prisidèti prie šiu mokymų gerinimo. Antra vertus, kariai itin pabrěžia savarankiško mokymosi apie kitą kultūrą svarbą: rodo siekị perduoti tarptautinejje operacijoje igytas žinias kitiems kariams, vyksiantiems ị tarptautines operacijas (pavyzdžiui, „Po šios misijos aš grišiu igijęs dar daugiau žiniu, kurias stengsiuos perduot kitiems. "[Tiriamasis nr. 3]), taip pat įvertina sąveikos su kitais kariais svarbą (pavyzdžiui, <...> susirašinėjau su tuo žmogumi, kurị turésiu keisti, jis man apibūdino kq reikia atsivežti, kaip atsiskaityti pinigais, kas reikalinga, kas nereikalinga, ka turèti. O apie šali - internetas. Visas žinias gavau neformaliai, ne iš institucijos. " [Tiriamasis nr. 9]). Karių bendradarbiavimas tarpusavyje dalijantis patirtimi iš dalies gali užpildyti institucinių mokymų metu paliekamas spragas ir turètų būti skatinamas kaip karių organizacinio sąmoningumo dalis.

Galima pridurti, kad karių kultūrinio išprusimo kompetencijų igijimas adaptuojantis kitoje kultūrineje aplinkoje vertintinas skeptiškai dèl kylančio 
pavojaus, kad kariai tik stebės aplinką, neįsitraukdami ị socialinę sąveiką su vietiniais gyventojais. Atsižvelgiant ị anksčiau išvardytas pastabas, galima teigti, kad karių kultūriniam išprusimui reikiamų kompetencijų igijimas turi būti suprantamas kaip ilgalaikis ir tęstinis procesas, t. y. kompetencijos turi būti igyjamos prieš kariams išvykstant ị tarptautinę operaciją ir tobulinamos tarptautinès operacijos metu.

\section{Išvados}

Empiriškai ịvertinus tarptautinèse operacijose dalyvavusių Lietuvos karių kultūrinị išprusimą, galimi apibendrinimai ir rekomendacijos Lietuvos karių kultūrinio išprusimo atžvilgiu:

1. Vienas svarbiausių karių kultūrinio išprusimo aspektų, kuris neatsiejamas nuo jų gebẻjimo išvengti stereotipinių nuostatų kitos kultūros atžvilgiu formavimo, yra karių motyvacija adaptuotis ir veikti kitoje kultūrineje aplinkoje. Tiriant karių kultūrinį išprusimą, minètieji aspektai išryškeja kariams analizuojant panašumus ir skirtumus tarp kultūrų. Šie aspektai daro itin didelę itaką karių kultūrinio išprusimo potencialui, todèl vykdant karių, dalyvausiančių tarptautinèse operacijose, atranką didesnis dèmesys skirtinas karių motyvacijos dalyvauti tarptautineje operacijoje analizei, nes:

a. kariai, turintys motyvaciją adaptuotis kitoje kultūrinėje aplinkoje, geba igyti ir pritaikyti kultūrines žinias ir įsitraukti ị socialinę sąveiką su kitos kultūros atstovais. Stereotipines nuostatas turintys kariai formuoja iškreiptą požiūrị ị kitą kultūrinę aplinką, todẻl jų socialinè sąveika su kitos kultūros atstovais yra neigiama arba neutrali;

b. kariai, suprantantys, kad tarptautineje operacijoje dalyvauja vykdydami savo organizacijos misiją ir tikslus ir, kad veikdami kitoje kultūrineje aplinkoje atstovauja savo organizaciją, geba adaptuotis kitoje kultūrinejje aplinkoje ir įsitraukti ị socialinę sąveiką su kitos kultūros atstovais nepriklausomai, ar jie yra motyvuoti adaptuotis kitoje kultūrineje aplinkoje;

c. institucinių mokymų metu nèra suteikiama pakankamai žinių ir igūdžių, reikalingų karių adaptacijai ir veiklai kitokiame kultūriniame kontekste, todèl kariai turi būti motyvuoti savarankiškai tobulinti jų kultūriniam išprusimui reikalingas kompetencijas.

2. Didesnis dèmesys skirtinas karių organizacinio sąmoningumo ugdymui, nes:

a. dalis karių dalyvauja tarptautinèje operacijoje skatinami išimtinai 
asmeninių motyvų ir nesieja dalyvavimo tarptautinejje operacijoje su savo atstovaujamos organizacijos misijos ir tikslų igyvendinimu. Kariams stinga sąmoningumo, kad jų veikla, įskaitant ir socialinę sąveiką su vietiniais šalies, kurioje vykdoma tarptautinė operacija, atspindi organizacijos misijos ir tikslų ịgyvendinimą;

b. kariai pažeidžia savo organizacijos reikalavimus siekdami adaptuotis kitoje kultūrineje aplinkoje. Nesilaikydami organizacijos reikalavimų kariai vis vien siekia organizacijos tikslų igyvendinimo - organizacijos reikalavimų nesilaikymas susijęs su karių siekiu didinti šalies, kurioje vykdoma tarptautinė operacija, vietinių pasitikejjimą jais. Todèl atkreiptinas dėmesys ị formalių organizacijos reikalavimų tobulinimo galimybes ir (ar) lankstesnị šių reikalavimų pritaikymą, atsižvelgiant î karių vykdomas funkcijas tarptautinès operacijos metu.

3. Institucinių mokymų metu pateikiamos žinios nèra pakankamos karių adaptacijai ir veiklai tarptautinès operacijos metu, todèl siekiant didinti karių kultūrinio išprusimo potencialą, turi būti plečiamas tarpkultūrinių, kultūros specifinių ir kalbos igūdžių spektras ir didesnis dèmesys skiriamas:

a. karių supažindinimui su kultūriniais skirtumais, galinčiais kelti jiems diskomfortą veikiant kitoje kultūrinèje aplinkoje;

b. remiantis tarptautinèse operacijose dalyvavusių karių patirtimi, dviprasmiškų situacijų analizei su kuriomis buvo susiduriama sąveikos tarp karių ir vietinių šalies, kurioje vykdoma tarptautinè operacija, metu;

c. institucinių mokymų pritaikymu atsižvelgiant $\mathfrak{i}$ karių veiklos pobūdị tarptautinès operacijos metu ir pateikiamų žinių analizei per šalies, kurioje vykdoma tarptautinè operacija, vietinių gyventojų mąstymo ir elgesio suvokimą;

d. instruktorių, buvusių šalyje, kurioje vykdoma tarptautinè operacija ir (ar) instruktorių, kilusių iš šalies, kurioje vykdoma tarptautinė operacija ịtraukimą i institucinius mokymus ir (ar) karių socialinės sąveikos skatinimui su kariais, grị̌usiais iš šalies, kurioje vykdoma tarptautine operacija;

e. karių kalbos kompetencijų gerinimui, didesnį dèmesị skiriant tiek karių kalbos, vartojamos šalyje, kurioje vykdoma tarptautinė operacija, igūdžių gerinimui, tiek supažindinant su galimomis kliūtimis dirbant su verteju. 